\section{AB1408-HPR INFLUENCE OF WEIGHT AND LIPID PROFILE IN RHEUMATIC PATIENTS WHO CHANGE FROM BIOLOGICAL THERAPY}

Rocio Segura, Maria del Carmen Abalos-Aguilera, Alejandra M. Patiño-Trives, Juan Vacas, Joaquin Sosa, Celestino Gil, Maria del Rosario Navarro, María del Carmen Castro Villegas, Rafaela Ortega Castro, Jerusalem Calvo Gutierrez, Desiree Ruiz, Montserrat Romero-Gómez, Ladehesa Pineda Lourdes, Alejandro Escudero Contreras, Eduardo Collantes-Estévez, Font Ugalde Pilar, Luis Jurado. Reina Sofia University Hospital, Rheumatology, Crdoba, Spain

Background: The lack of efficacy of biological therapies in rheumatic patients causes a change of treatment, usually to another biological therapy. A significant number of studies have been published in relation to the reasons that cause this inefficacy, ${ }^{(1,2,3)}$; however, no studies have evaluated the involvement of the weight and lipid profile of patients in this process.

Objectives: To analyze the influence of weight and lipid profile in the relapse and change of biological therapy.

Methods: Retrospective-descriptive study. Rheumatic patients in treatment with biological therapies were recruited from January 2016 to December 2018. Sociodemographic data were collected (age and sex), along with anthropometric variables (weight, height, waist circumference and hip perimeter), toxic habits, comorbidities and variables related to the treatment. Associations between variables were analyzed using a Chi-square and $\mathrm{T}$ student. P-values $<0.05$ were considered statistically significant. The spss v.19 program was used for data analysis.

Results: Two hundred and nine patients were enrolled, of which 80 $(38.3 \%)$ were male and $129(61.7 \%)$ were female. The mean age (SD) was 48.912 .8 years. One hundred and twenty patients $(57.4 \%)$ suffered rheumatoid arthritis, $35(16.7 \%)$ spondylitis, 29 (13.9\%) psoriatic arthritis and $10(4.8 \%)$ spondyloarthritis. One hundred and fifty-three $(73.2 \%)$ had not switches of biological therapy, 51 (24.4\%) switched of biological therapy once and $5(2.4 \%)$ three or more times. Statistically significant differences were found in the obese males who switched of biological therapy in relation to obese males who not switched $(35.6 \%$ vs. $11.1 \%)$. Accordingly, the percentage of patients with hyperlipemia that switched of biological therapy was significantly higher than those who did not $(29.4 \%$ vs. $13.1 \%)$.

The years of evolution and diagnosis we also involved, so that patients with more years of evolution and more years from the diagnosis had a higher percentage of switched ( $p=0.006$ IC $95 \%-17.22,-0.96$ and $p$ $=0.042-18,32 ;-037$ respectively).

Conclusion: Being obese male and with hyperlipidemia could be a risk factor that would condition the lack of response to a biological therapy and thus the need of switching to another.

\section{REFERENCES}

[1] Glintborg B1, stergaard M, Krogh NS, Tarp U, Manilo N, Loft AG, Hansen A, Schlemmer A, Fana V, Lindegaard HM, Nordin H, Rasmussen C, Ejstrup L, Jensen DV, Petersen PM, Hetland ML. Clinical response, drug survival and predictors thereof in 432 ankylosing spondylitis patients after switching tumour necrosis factor $\alpha$ inhibitor therapy: results from the Danish nationwide DANBIO registry. Ann Rheum Dis. 2013 Jul;72(7):1149-55. doi: 10.1136/annrheumdis-2012-201933. Epub 2012 Aug 31.

[2] Navarro-Compn V, Plasencia-Rodrguez C, de Miguel E, Diaz Del Campo P, Balsa A, Gratacs J. Switching biological disease-modifying antirheumatic drugs in patients with axial spondyloarthritis: results from a systematic literature review. RMD Open. 2017 Oct 10;3(2):e000524. doi: 10.1136/ rmdopen-2017-000524. eCollection 2017.

[3] Ganzetti G, Campanati A, Bettacchi A, Brandozzi G, Brisigotti V, Bugatti L, Cataldi I, Filosa G, Giacchetti A, Lemme G, Morresi L, Nicolini M, Postacchini V, Ricotti G, Rosa L, Simonacci M, Offidani A. Switching from a biological therapy to another biologic agent in psoriatic patients: the experience of PsOMarche group. G Ital Dermatol Venereol. 2018 Feb;153 (1):5-10. doi: 10.23736/S0392-0488.16.05463-8. Epub 2016 Nov 15.

Disclosure of Interests: Rocio Segura: None declared, Maria del Carmen Abalos-Aguilera: None declared, Alejandra M. Patio-Trives: None declared, juan vacas: None declared, Joaquin Sosa: None declared, Celestino Gil: None declared, Maria del Rosario Navarro: None declared, Mara del Carmen Castro Villegas Paid instructor for: MSD, Abbvie, Pfizer, Janssen, Lilly, Roche, Rafaela Ortega Castro: None declared, Jerusalem Calvo Gutierrez: None declared, Desiree Ruiz: None declared, Montserrat Romero-Gmez: None declared, Ladehesa Pineda Lourdes: None declared, Alejandro Escudero Contreras: None declared, Eduardo Collantes-Estvez Consultant for: UCB Pharma, MSD, AbbVie, Novartis, Janssen, Font Ugalde Pilar: None declared, Luis Jurado: None declared
DOI: 10.1136/annrheumdis-2019-eular.7933

\section{AB1409-HPR INFLUENCE OF THE COMPANION ANIMALS IN THE PERCEPTION OF OUTBREAKS IN RHEUMATOLOGICAL DISEASES}

Rocio Segura, Guadalupe Ortega, Joaquin Sosa, Marta Crespn, Celestino Gil, Trinidad Montes, Juan Vacas, Maria del Rosario Navarro. Reina Sofia University Hospital, Rheumatology, Crdoba, Spain

Background: Few papers analyze the health benefits of living with companion animals ${ }^{(1)}$. A significant number of studies have been published in relation to dogassisted therapies for people with Alzheimer's or people with brain injuries, but al of them analyzed a reduced sample number ${ }^{(2)}$ or did not show a good methodological structure ${ }^{(3)}$. Regarding the reduction of pain and quality of life, different studies showed positive results in the use of assisted therapies with dog ${ }^{(4)}$. However, this subject has not been evaluated yet in patients suffering Rheumatologic diseases.

Objectives: The main objective of this study is to evaluate the influence of companion animals on the perception of outbreaks in rheumatological diseases. Secondary objective: to analyze if having companion animals affected the general state of health or the degree of physical activity.

Methods: Prospective descriptive study. Consecutive patients attending rheumatology consultation were recruited during the month of October 2018. Sociodemographic data were collected (age, sex, cohabitation with companion animals, type of exercise performed) along with Beck questionnaires to assess depression, SF-12 to assess quality of life, and VREM (Spanish Short Version of the Minnesota Leisure Time Physical Activity Questionnaire) to assess the degree of physical activity. Associations between variables were analyzed using a Chi-square and $T$ student P-values $<0.05$ were considered statistically significant. The main variables: dog, cat and other animals, were analyzed separately and then unified in a new variable called companion animals. The spss v.19 program was used for data analysis.

Results: Seventy one patients were enrolled, of which 30 (42.3\%) were male and $41(57.7 \%)$ were female. The mean age (SD) was 58.7815 .31 years. Thirty two patients (45.1\%) suffered rheumatoid arthritis, $8(11.3 \%)$ spondylitis, $8(11.3 \%)$ osteoarthritis, and patients with fibromyalgia, becet, gout and scleroderma were present in a lower percentage. Regarding the coexistence with companion animals, 19 (26.8\%) lived with dogs and 7 $(9.9 \%)$ with cats.

The results of this study did not demonstrate any significant relationship between the duration of the outbreaks, the depressive state or the degree of physical activity and the coexistence with companion animals. However, statistically significant differences were found in the quality of live perceived by patients living with dogs in relation to patients without companion animals, so that we found higher scores in the mental SF-12 (56.5 vs 44$),(p=0.036,95 \% \mathrm{Cl}-24.41,-0.80)$, the physical SF-12 (51.7 vs 39$),(\mathrm{p}=0.042,95 \% \mathrm{Cl}-25 ;-0.5)$ and total SF-12 (56.11 vs 43.8), $(p=0.018,95 \% \mathrm{Cl} 22.4,-2.2)$.

Conclusion: Coexistence with dogs improves the perception of the quality of life of patients, both physically and mentally.

\section{REFERENCES}

[1] Saito T, Okada M, Ueji M, Kikuchi K, Kano K. [Relationship between keeping a companion animal and instrumental activity of daily living (IADL). A study of Japanese elderly living at home in Satomi Village. Nihon Koshu Eisei Zasshi. 2001 Jan;48(1):47-55.

[2] Folch A, Torrente M, Heredia L, Vicens P. Effectiveness of dog-assisted therapy in the elderly. A preliminary study. Rev Esp Geriatr y Gerontol. 2016 Jul-Aug;51(4):210-6. doi: 10.1016/j.regg.2015.12.001. Epub 2016 Feb 5

[3] Tabares Snchez, C, Castro, FV, Snchez Herrera, S, Gmez Acuas, M. Estado del arte sobre los efectos de la terapia asistida con perros en el tratamiento de enfermos de alzheimer. International Journal of Developmental and Educational Psychology [Internet]. 2013;1(2):271-281. Recuperado de: https://www.redalyc.org/articulo.oa?id=349852060025.

[4] Lust E, Ryan-Haddad A, Coover K, Snell J. Measuring clinical outcomes of animal-assisted therapy: Impact on resident medication usage. Consult Pharm J Am Soc Consult Pharm 2007;22(7):580-5.

Disclosure of Interests: None declared

DOI: 10.1136/annrheumdis-2019-eular.8177 